\title{
PEMBUATAN PORTAL INFORMASI WEB SEBAGAI TEROBOSAN TERBARU UNTUK LAYANAN REFERENSI
}

\author{
Prasetyo Adi Nugroho*
}

\begin{abstract}
ABSTRAK
Perkembangan jaman yang semakin maju telah mengubah banyak hal terutama perkembangan teknologi yang semakin pesat. Memaksa masyarakat untuk mengikuti arus yang pada dasarnya adalah globalisasi. Seperti halnya perpustakaan kini telah berkembang mengikuti arus globalisasi dan arus perkembangan teknologi informasi yang dibutuhkan pun beragam dibedakan dari jenis usia dan jenis keperluan masing-masing. Dari situ perpustakaan berusaha untuk memberi kepuasan kepada para pemustakanya. Kecocokan informasi yang ada, dengan kebutuhan pemustaka merupakan salah satu cara kita mengoptimalkan akses informasi. Sistem penemuan kembali informasi berguna untuk mencocokkan apa yang tersedia, dengan apa yang dibutuhkan oleh pemustaka perpustakaan. Layanan referensi online berbentuk portal web adalah salah satu jawaban dari kebutuhan masyarakat atau pemustaka yang haus akan informasi.
\end{abstract}

Kata kunci: layanan referensi, portal online, perpustakaan

\section{LATAR BELAKANG}

Internet saat ini telah menjadi bagian yang tidak terpisahkan dari kehidupan kita. semua aspek kehidupan telah memulai memanfaatkan fasilitas internet, tidak hanya perusahaan yang ingin memasarkan produknya secara global. Tetapi juga pemerintahan, organisasi, partai politik, yayasan, lembaga dan bahkan individu juga telah menggunakan internet untuk mendapatkan kemudahan dalam memberikan layanan dan informasi, juga untuk kemudahan perluasan dan pengembangan bisnis. Setiap waktunya internet semakin memasyarakat di Indonesia hal ini ditandai dengan semakin banyaknya pengguna internet dari tahun ke tahun dan akan terus bertambah.

Perpustakaan sebagai lembaga informasi yang tak mungkin lepas dari pengaruh internetpun mulai melakukan berbagai macam inovasi untuk meningkatkan kenyamanan para pengguna perpustakaan. Perpustakaan tinggi negeri maupun swasta di Indonesia saling bersaing secara kreatif guna meningkatkan kualitas penyampaian informasi yang baik.

Sementara, pada jaman sekarang semua aktivitas yang dilakukan oleh manusia berhubungan dengan internet. Termasuk juga dalam kegiatan pencarian informasi. Dengan mengandalkan jaringan (network), pengguna perpustakaan dapat menelusur informasi yang tersedia melalui web perpustakaan. Tetapi di dalam website/portal informasi perpustakaan belum menyertakan setiap layanan yang ada di perpustakaan. Rata-rata website/portal informasi hanya berisi pengenalan perpustakaan dan jenis-jenis layanannya saja. Jarang ada website/portal informasi perpustakaan yang memberikan layanan langsung pada website mereka.

Layanan referensi yang berada didalam sebuah perpustakaan menjadi bagian yang sangat penting. Karena layanan referensi merupakan salah satu kegiatan pokok yang dilakukan di perpustakaan yang khusus melayangkan koleksi referensi kepada para pengunjung atau para pemustaka. Adanya layanan referensi membantu para pemustaka untuk menggunakan koleksi bahan pustaka, menelusur informasi dan mengarahkannya dalam temu kembali. Seiring perkembangan teknologi yang semakin pesat mendesak para ahli teknik informatika atau ahli teknologi untuk memanfaatkanya. Salah satunya yang berkembang di internet yaitu adanya sebuah layanan referensi secara online. Layanan ini

* Pustakawan Perpustakaan Universitas Airlangga

E-mail: prasetyo.adi@staf.unair.ac.id 
memuat data rujukan dalam bentuk elektronik yang nantinya para pemustaka dapat mengaksesnya melalui internet. Kapan pengaksesannya tidak terbatas oleh ruang dan waktu.

Berdasarkan permasalahan diatas, penulis melihat ini sebagai peluang untuk bisa memberi konsep suatu produk informasi digital berbentuk portal informasi. Hasil dari produk akan kami terapkan di salah satu layanan perpustakaan yakni layanan referensi.

\section{KAJIAN PUSTAKA}

Menurut American Library Association yang dikutip oleh Murniaty $(2006,4)$ "pelayanan referensi merupakan sebagian dari pelayanan perpustakaan yang secara langsung berhubungan dengan pengguna dalam memberikan informasi dan pengguna perpustakaan untuk kepentingan studi dan riset."

Sejalan dengan pernyataan di atas, Reference User Service Association (selanjutnya disingkat RUSA) mengemukakan bahwa "pelayanan referensi meliputi transaksi referensi dan kegiatan lain yang melibatkan penciptaan, manajemen, dan penilaian informasi atau penelitian sumber daya, peralatan, dan jasa" (RUSA, 2008).

Transaksi referensi merupakan konsultasi informasi dimana staf perpustakaan merekomendasikan, menafsirkan, mengevaluasi, dan/atau menggunakan sumber daya informasi untuk membantu orang lain untuk memenuhi kebutuhan informasi tertentu. Transaksi referensi tidak termasuk instruksi formal atau pertukaran yang memberikan bantuan dengan lokasi, jadwal, peralatan, perlengkapan, atau pernyataan kebijakan (RUSA, 2008).

Dari penjelasan tersebut, dapat diketahui bahwa pelayanan referensi pada perpustakaan sangat penting dalam pemenuhan informasi penggunanya. Pelayanan

referensi memberikan informasi langsung kepada pengguna baik informasi yang ilmiah untuk kepentingan studi dan riset maupun informasi yang bersifat non ilmiah. Memberikan petunjuk atau bimbingan tentang pemanfaatan sumber informasi yang ada di perpustakaan ataupun sumber-sumber yang ada di luar perpustakaan.

Seiring perkembangan teknologi informasi, layanan referensi mengalami perkembangan dalam memberikan pelayanan seperti yang dikenal dengan referensi online, atau dikenal dengan istilah layanan referensi virtual, referensi elektronik, referensi maya, referensi digital, dan sebagainya. Layanan referensi virtual dimulai secara elektronik dimana pelanggan menggunakan komputer atau teknologi lain untuk berkomunikasi dengan staf pelayanan publik tanpa hadir secara fisik (RUSA 2008).

Internet dan teknologi turut mengubah pemberian layanan referensi di perpustakaan, peralihan layanan secara konvensional ke bentuk digital sekarang menjadi perhatian dalam perkembangan layanan. Layanan referensi juga dapat dihadirkan melalui media komunikasi yang lebih luas, lebih dari sekedar tatap muka. Perkembangan ini juga memengaruhi sikap pustakawan dan perpustakaan dalam memberikan layanan referensi di Perpustakaan Perguruan Tinggi. Hal ini dilakukan agar dapat menjangkau pemustaka yang mungkin tidak dapat langsung datang ke perpustakaan dikarenakan jarak dan waktu.

\section{METODE}

Tulisan ini hasil dari renungan penulis dengan didukung studi pustaka, baik dalam bentuk cetak maupun online.

\section{PEMBAHASAN}

Dari semua aktivitas di perpustakaan, layanan referensi adalah salah satu yang terkena dampak paling dahsyat. Jika dulu orang "terpaksa" menggunakan layanan referensi karena akses ke sumber informasi yang relatif terbatas, sekarang dengan internet tingkat ketergantungan sudah jauh berkurang. Sebagian orang mungkin mengatakan layanan referensi sudah mati. Tetapi mereka lupa bahwa TI memang membawa kemudahan dalam mengakses informasi tetapi juga menimbulkan masalah baru: information overload and complexity.

Portal informasi yang akan dikembangkan adalah portal web yang berisi informasi mengenai sumber referensi, misalnya katalog online, ensiklopedia online,

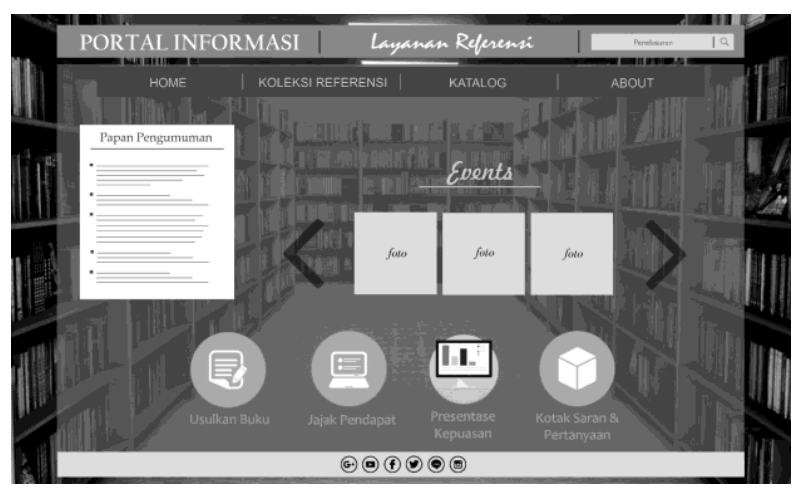

Gambar 1. Menu Home. 
abstract online dan lainnya. Tujuannya adalah untuk membantu para pengguna dalam mempermudah pencarian informasi-informasi yang sesuai dengan kebutuhan mereka. Selain itu di dalam portal informasi ini akan tersedia sumber informasi berbentuk elektronik atau digital.

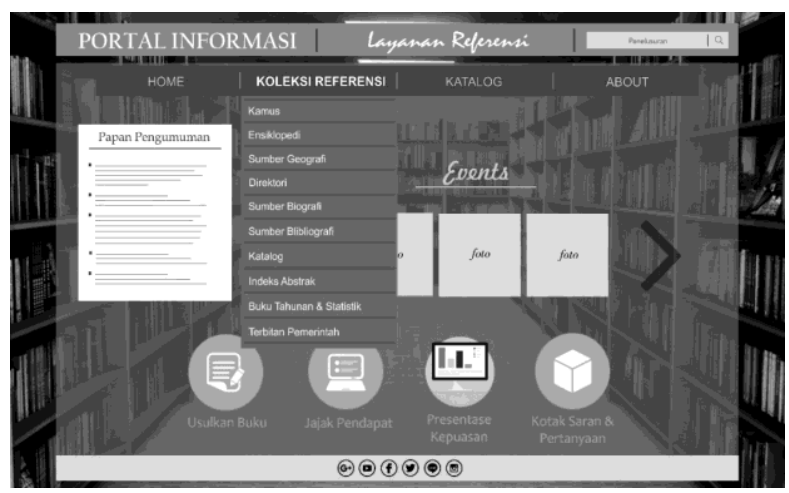

Gambar 2. Menu Koleksi Referensi

\section{Home}

Home merupakan halaman awal pada portal informasi, terdapat beberapa menu yang disajikan dalam web tersebut yakni home, koleksi referensi, katalog, about, mesin pencari, beberapa gambar material non buku yang jika di klik dapat menuju ke halaman informasi gambar tersebut, mesin pencarian, informasi-informasi terbaru, dan tulisan-tulisan yang mendukung web tersebut sebagai Portal Informasi Layanan Referensi.

\section{Koleksi Referensi}

Menu Koleksi Referensi memiliki beberapa submenu seperti gambar diatas, berikan tentang semua tersedia di layanan referensi, pengunjung dapat dengan mudah

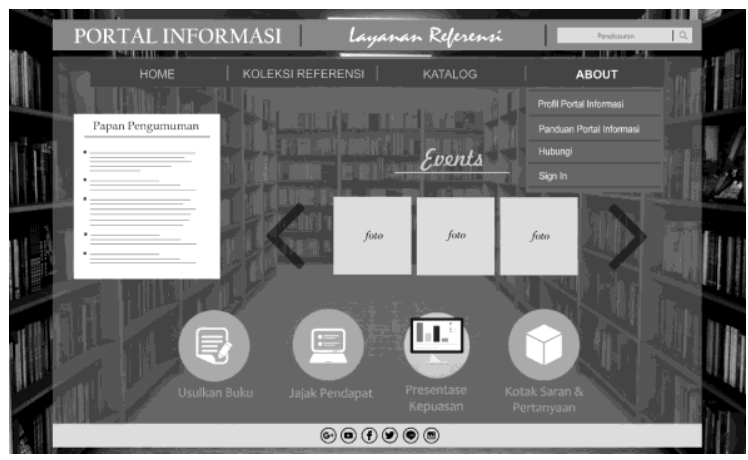

Gambar 3. Menu About mencari apa yang mereka butuhkan, dengan adanya portal informasi online seperti ini, pengunjung dapat mengakses dimana saja tanpa harus berkunjung ke perpustakaan. Di page ini terdapat beberapa subtopic diantaranya: Kamus, Ensiklopedi, Sumber Geografi, Direktori, Sumber Biografi, Indeks Abstrak, Buku Tahunan \& Statistik.

\section{About}

About merupakan menu yang menyajikan informasi terkait portal informasi layanan referensinya meliputi sub menu sebagai berikut:

1. Profil portal informasi $\rightarrow$ berisi informasi seputar website beserta sejarah pembentukan portal informasi dan segala hal mengenai portal informasi layanan referensi itu sendiri.

2. Hubungi $\rightarrow$ informasi mengenai pengelola dan kontak yang dapat dihubungi oleh konsumen apabila memiliki sebuah pertanyaan yang mendalam mengenai kerjasama ataupun hal-hal privasi tentang portal informasi.

3. Sign In $\rightarrow$ konsumen dapat melakukan sign in apabila ingin berpartisipasi dalam mengembangkan portal informasi dengan membuat akun yakni mendaftarkan diri terlebih dahulu dan memasukkan alamat email.

Dengan menggunakan portal informasi ini pengguna bisa mencari informasi yang dibutuhkan dengan lebih cepat dikarenakan dalam portal informasi ini terdapat fitur pencarian berdasarkan advance search sehingga memudahkan pengguna dalam portal informasi ini. Terdapat juga fitur chit-chat yang mana nanti pengguna bisa menanyakan melalui semacam video call/live streaming kepada admin portal informasi mengenai informasi-informasi yang kurang dimengerti.

\section{PENUTUP}

Melalui portal informasi sebagai pembaharuan layanan Referensi, diharapkan pengguna dapat lebih memaksimalkan penggunaan layanan referensi sebagai rujukan mereka dalam pencarian dan penelusuran informasi. Selain itu penggunaan portal informasi ini juga sebagai jalan pintas untuk lebih mengefektifkan dan mengefisienkan proses pelayanan referensi yang selama ini dinilai pengguna terlalu menghabiskan waktu yang lama. Informasi yang ada di dalam layanan referensi ini juga sangat relevan karena sumber informasi yang kami peroleh berasal langsung dari sumber referensi yang berada pada salah satu perpustakaan, jadi para pengguna 
tidak perlu khawatir apakah informasi tersebut relevan atau tidak.

\section{DAFTAR PUSTAKA}

Murniaty. 2006. Promosi Jasa Pelayanan Referensi di Perpustakaan. http://repository.usu.ac.id/bitstream/1 23456789/1817/1/06009263.pdf. 15 April 2014.
Reference and User Services Association (RUSA). 2003. Professional Competencies for Reference and User Services Librarian. http://www.ala.org/rusa/resources/ guidelines/professional. 31 Januari 2014.

-----. 2008. Definitions of Reference. http://www.ala.org/ rusa/resources/guidelines/definitionsreference. 31 Januari 2014. 